\title{
Ancestor Non-worship in Mampruli
}

Tony Naden, Ghana Institute of Linguistics, Literacy and Bible Translation,
Walewale, N.R., Ghana

Abstract: This paper first draws attention to the necessity of careful choice of terminology in ethnological discussions of the areas of culture often termed 'traditional religion', especially in the use of terms like 'worship'. There follows a discussion of some of the methodological difficulties in this area, with the suggestion that a lexicological approach to the vocabulary used by members of the society studied may make a useful contribution to understanding here. The second part presents tabulated lexical data from the Western Oti / Volta languages which illustrates the problems and possibilities discussed.

Keywords: LANGUAGES, LINGUISTICS, WEST AFRICA, GUR, RELIGION, WORSHIP, GOD, GODS, DIVINATION, SACRIFICE, COMPARISON, LEXICOLOGY, SEMANTICS, LEXICOGRAPHY, DICTIONARY, VOCABULARY, WORDLIST

\begin{abstract}
Abstrait: Inapplicabilité du mot 'culte' au respect envers les ancêtres langue mampruli. Cette étude présente d'abord une esquisse des problèmes et possibilités qu'offerent les études du domaine frequemment nommé 'la religion traditionnelle'. La nécessité de choisir une terminologie avec le plus grand soin est signalée, surtout dans l'emploi du terme 'culte' ou ses synonymes. Les problèmes méthodologiques sont considérés, avec proposition que l'analyse sur le plan lexicologique puisse clarifier quelques aspects de ce sujet complexe. Enfin on offre des données sur le vocabulaire des langues Oti / Volta pour illustrer les problèmes ainsi que les possibilites d'une telle approche.
\end{abstract}

Mots Clef: LANGUES, LINGUISTIQUe, AFRIQUE OCCIDENTALE, LANGUES VOLTAIQUES, RELIGION, CULTE, DIEU, DIEUX, DIVINATION, SACRIFICE, COMPARATISME, LEXICOLOGIE, SEMANTIQUE, IEXICOGRAPHIE, DICTIONNAIRE, VOCABULAIRE, LISTE-DE-MOTS

\section{Introduction: Roots of This Study}

In violation of all the canons of freshman composition and theme-construction, this paper has two, albeit related, aims. The first is to consider the concept and terminology of the Anthropology of Religion and the treatment of religion as a heading in ethnographic description, with especial reference to the use and usage of the term "worship". The second is to consider the lexical field of what would normally be considered the terminology of traditional religion, in the 
Mampruli language of northern Ghana and its congeners. This empirical investigation is based in the Western Oti / Volta Lexinotes" on "sun" and "God" (\#3) and traditional religion (\#14).

As has been pointed out by the terminologist Fred Riggs (e.g. 1986: 2) it is the tradition in the social sciences to use "Delphic" language - to develop terms for new concepts by redefining and reusing existing or ordinary-language terms rather than inventing neologisms. In many cases this only results in global polysemy of terms, local ambiguity usually being avoided by explicitly giving the definition currently in use in loco (Riggs quotes Humpty Dumpty - "When I use a word ... it means just what I choose it to mean, neither more nor less"). However there is a problem in some cases where important paradigm- or worldview-presuppositions are embedded in the existing or ordinary language use of the term; in these situations there may be an unconscious carryover of conceptual baggage either into the thinking of the investigator reusing the term or - contrary to the writer's intention - into the way in which the audience understands the discourse in which it is used. This is surely a danger with the term "religion" and some of its hyponyms, amongst which I am particularly concerned here with "worship". Assuming the use of English as the language of communication (let's not open any more cans of worms!) the term "religion" for a Marxist, a humanist, a Roman Catholic or Evangelical Christian, a Muslim, Buddhist and so on, has a meaning, in several senses of the word "meaning", loaded with all sorts of different salient components, and where the communicator and the receptor differ in their personal positions the success of the communication is obviously in the greatest jeopardy.

The situation is complicated in anthropological discussion because, in addition to the connotations of the terminology to the speaker and hearer, there is also the fact that the topic of the discourse is some social group which has its own worldview which is probably different again. Whether or not we jump on currently popular bandwagons and wave the banner of postmodernism, it is certainly generally recognised these days that in presentations in the social sciences of particular societies it is necessary to be more attentive to the voice of the people concerned, the 'stories' or viewpoints of the members, or whatever our terminological predilection, and not allow our interpretation and analysis to be wholly coloured by our own worldview and agenda. This is of course by no means wholly new, though it may be more frequently and pugnaciously stated in current discussion of anthropological practice. In my own field of West African societies, and specifically those speaking Gur languages (Naden 1989 ) in Northern Ghana and adjacent areas, we find Jack Goody in the 'fifties referring to "interpretations of symbolic meanings which are not demonstrably explicit to the actor" (1956 [1961]: 75, fn.) and emphasising that these need checking empirically.

The danger is of swinging the pendulum too far in the opposite direction. Some development projects aim for appropriate technology and non-intrusive methods and end up leaving people with nothing beyond their traditional 
methods which have kept them poor and undernourished. [We had neighbouring agricultural volunteers who wanted to introduce donkey carts instead of internal-combustion transport: then they rejected factory-built metal-framed carts in favour of locally-made wooden ones; then they wanted to get rid of pneumatic-tyred steel car wheels and use wooden wheels, but there is no local tradition of wheelwrighting, no knowledge of whether local timbers are suitable in local climatic conditions, so the wooden wheels broke and people were back to carrying things on their heads or running diesel tractors as local public transport.] Comparably if the social scientist merely presents an unedited authentic member text with a take-it-or-leave-it stance the audience remains as lacking in understanding of the society covered as before, or makes a do-ityourself interpretation without the benefit of the training and exposure of the researcher.

These tensions are well illustrated in the field particularly under scrutiny here, that of ritual practices usually lumped by the ethnographer under the heading of 'religion', and specifically such studies in traditional African societies $^{2}$. On the one hand there is a wide disparity in the personal ideologies of the researchers, and on the other a considerable world-view gap between them and the peoples studied. At first sight we might consider the latter gap to be bridged by publications by educated members of African ethnic groups, such as the well-known work of John Mbiti (e.g. 1969, 1970) for East Africa, or Peter Sarpong (e.g. 1974) in my own area. Quos honoris causa nomino - they do at least as good a job as non-African ethnographers in dealing with a very difficult problem. However, further consideration shows that a person who is a published author in a world language and a prominent academic, let alone a Roman Catholic bishop, is rather far from any traditional African roots his family may once have had. There is also the tendency to feel that because one is a genuine indigene one can generalise one's own experience beyond the confines of one's actual observation, so that Mbiti's Kenyan background is made to speak for Africa, and Sarpong projects his Akan experience to be that of Ghana as a whole. Even nearer home, I may cite Sylvester Nkrumah's combination of useful concrete observations on a society near his home area with vague statements that extrapolate to 'African' worldview (1993). A "native anthropologist" (his own term) who shows a good appreciation of this problem is Abasi (1995, 448-9), recognising that even being a native speaker of the language can be a double-edged weapon.

My contention here impinges on the discussion initiated by Kopy toff (1971 - see, e.g., Mendonsa 1976, and, most recently, McCall 1995) - with whom I largely agree as far as my understanding goes of the Mamprusi and similar societies considered here. At least the onus of proof would seem to be on anyone who would wish to stress the appropriateness of using terms like 'supernatural' to describe the traditional attitudes of an African group to the ancestors, and would require that that proof should include volunteered statements of non-deculturated members of the society, not merely responses to research- 
ers' questions. However the focus in this paper is slightly different, as it is particularly the use of the term 'worship' with which I am concerned here - my
title is not 'non-(ancestor-worship)'!

What I would like to suggest is that a careful lexicological study of the vocabulary used by members of the society under consideration can help towards objectivity in such situations. At the very least the bilingual lexicographer is conscious of the pitfalls awaiting the student of cross-cultural meaning, and in addition will be aware of various techniques of analysis and presentation which may help to avoid the worst distortions. With a view to illustrating this contention, part 2 below presents the relevant vocabulary of the Mamprusi people whose language and culture is my primary area of research, in conjunction with the vocabulary of the related languages of the Western Oti / Volta (W.O/V) subgroup of Gur, largely based on the Lexinotes mentioned above.

\section{Religion and Worship in Anthropology}

1.1 Religion: The starting point for an attempt at a modern 'etic' definition of terms such as "religion" is Rudolf Otto's 'Idea of the Holy' (Otto 1923 / 1950). This derives the origin of religion (in the evolutionistic model which was the paradigm of choice at the time) from the feeling of awe in the face of the unusual or incomprehensible ('mysterium tremendum') which before any personification or theologising may be described as recognition of 'the numinous'. With this we may compare the OED ${ }^{3}$ definition of "Religion" (sb.3): "action or conduct indicating a belief in, reverence for, and desire to please, a divine ruling power; the exercise or practice of rites or observances implying this." Here the numinous object of awe has become "a divine ruling power".

A further degree of interpretation and specification is found in 'Notes and Queries' (R.A.I. 1951: 175): "Religion is characterized by a belief in, and an emotional attitude towards, the supernatural being or beings, and a formal mode of approach - ritual - towards them". Here the somewhat-imprecise 'divine' has become "supernatural" which certainly introduces the western post-Renaissance contrast of nature and supernature. The subsequent sections mention "Beliefs concerning Man" (soul - death - after-life - abode of the Dead - fate of the Dead - reincarnation), "Beliefs concerning Supernatural beings and Agencies" (spirits - cults - officiants - sacred places) and "Forms of Ritual" (prayer - offerings - actions - taboo - oracles - divination ordeal - oath - ritual language) - (ibid.: 176-187).

There follows a major division which deals with "Magical Beliefs and Practices", stating that "In magic, no appeal is made to spirits" (ibid.: 187). This is all very clear as long as we are confident that we can identify a 'spirit' when we (don't) see one! My main contention here is that in many parts of northern Ghana sacred places, oaths, ritual, taboo, divination and other things listed in 
the 'Religion' sections above do not involve anything that can be appropriately designated 'spirit', 'divine / supernatural being', or 'spiritual $X$ '.

This key problem of terminology is specifically seen in the (topic- and geographical-) area in focus here in the case of the constant use by English-speaking ethnographers of the terms "spirit", "spiritual" and derivatives (similarly French esprit..., German Geist..."). The only term in the local languages rendered by speakers in English as "spirit" is "SI- -GA / -SI (MP siiya / siisi; DB shii / shihi; KLA siig / siis; BL chiik / chiisa). This is 'spirit' in the sense of that immaterial part of a human being which is present in the living but absent in the dead; this is what has the experiences contained in dreams, and witches' spirits (in some areas) travel, or send out a familiar, or use some apparatus to catch and consume (parts of) people's spirits causing otherwise inexplicable lingering illness and death. On the other hand, when scholars offer translations like "shrine-spirit/s" (for *BAG- or *BUG-: 2.2.3 Vocabulary \#10 below), "spirit of the earth(-shrine)" (for "TIN-, "TIN-GBAN: 2.2.2 Vocabulary \#6), and "guardian spirit" or "spirit guardian" (for "SIG-: 2.3.2 Vocabulary \#12), or refer to the "spiritual" activities, forces, or nature of what is being done in divination and sacrifice, they are not reflecting members' ways of speaking of these things but adding a reinterpretation. And the standpoint of the reinterpretation is the western scholar's materialism, so that to call something "spiritual" is equivalent to calling it "imaginary", "non-existent" or "unreal". Thus Fortes (1980: vii) describes the scholarly stance as "agnostic", but it is clear from the rest of the piece that it is rather a dogmatic materialism - "Krishna is not really brought down amongst his devotees and Tallensi ancestors are not really present on or in the shrine dedicated to them" (ibid.: xii).

The other problem with the 'Notes and Queries' definition of magic, which also states that "the desired end is believed to be achieved directly by the ritual technique itself, i.e. by the use of the appropriate actions, objects or words", is that it could perfectly well cover the priming of a pump, bleeding of brakes, tuning of a radio set or surfing the internet. 'Magic' is the science of people I despise. Old-time explorers laughed at the tendency of 'primitives' to label modern technology as "white man's magic", but one might look at it the other way and see that the colonised were recognising the colonialists' technology as the same sort of thing as their own techniques which the 'white-man', feeling superior, labelled as "magic" or "superstition". What I am arguing for is not radical cultural relativism, but the recognition that in exploration of meanings crossculturally - which is a large part of the work of both the anthropologist and the bilingual lexicographer - we need to be very slow to slap off-the-peg labels from one language on the concepts of another, let alone import all their connotative baggage along with them.

1.2 Worship: This caveat is particularly necessary when we come to a term like "worship". The normal use of the English term has a rather specific set of senses and connotations: note that even French, for instance, has no real 
equivalent, both 'culte' and 'vénération' only covering limited parts of the area designated by the English word; the former particularly, along with the Dutch 'godsdienst' and 'eredienst', corresponding rather to the English "(religious) service", and focussing more on ritual practice than on attitude. "Worship", however, has its etymology in 'worth', the OED defining "Worship" (v.1) as "To honour or revere as a supernatural being or power, or as a holy thing; to regard or approach with veneration; to adore with appropriate acts, rites and cerema nies", where only the third clausula corresponds to "culte", "eredienst", and etymologically we compare the entry under (sb.1) - "The condition (in a person) of deserving ... honour". The English term "worship", therefore, primarily refers to a virtue in a person or object which elicits a feeling of respect or awe (as in Otto's 'numinous'), and only then to appropriate behaviour. Against this sort of background of associations, a literary / theological writer like Tolkien can even define "Divinity" as "the right to power (as distinct from its possession), the due of worship, in fact 'religion"' (1964: 27).

My argument here, then, is that, in writing in English of unfamiliar cultural systems, the word "worship" should be related to recognised or ascribed 'worth', and is not to be used as a mere synonym of "ritual". I would further suggest that for the Mamprusi, and probably for a number of neighbouring and related ethnic groups, the 'culte' of the ancestors is more an extension of the 'culte' of respect and prestations offered to living elders, rather than being rendered, by the mere fact of death 4 , a totally different relation of 'worship' of the 'supernatural'. If one challenges an accepted usage one is open, of course, to the demand that one offer a better alternative: one possibility is "ancestor veneration" which McCall uses (1995: 257) in his summary of Kuper 1982 - 'veneration' can apply to the living, but also has "religious" overtones (and moreover has a corresponding French term which is no faux ami).

1.3 Methodological problems: The above discussion is theoretical - theological even - but there are practical methodological problems in ethnographic and linguistic research in this area of culture which are intensely practical and pressing for the field-worker.

1.3.1 The first type of difficulty, both in the chronological and in the logical sense, may be labelled as elicitation problems. How does a researcher in a culture of which he is not a native - or to which he is returning after years of alien residence and education (Abasi 1995), or of which he is a member but needs to determine how far his understandings are typical of those of fellow-members or are rather idiosyncratic - find out what people think and do about such matters? This subject area is particularly apt to be treated as esoteric - these things "are not talked about" from conviction that these are arcane matters, in which revelation of secrets to outsiders may lead to retribution being visited on the source or recipient of the revelation, or may simply deprive the practice concerned of its efficacy, either at the time or permanently. On the 
other hand it may be that they "are not talked about" from lack of interest outside the actual performance itself. The Mamprusi and their neighbours are not particularly prone to secrecy and protection of esoteric doctrines and practices by deviousness or threats ${ }^{5}$. On the other hand the researcher may not be prepared for a non-ideological approach to life, where even in areas we may want to label 'religious' there is no system of doctrine. or myth underlying the practices. This is much more the situation in this area6: people can describe a festival, ritual, or indeed a technological procedure, if they are just about to be involved in it (or have just been involved), but not at other times. Even the traditional month-names (Naden forthc.) can be given in correct order for the current season by many people who seem unable to give them for the other end of the year.

The danger in both these cases is the leading question. Where people do not volunteer information it must be elicited, but until you know a good deal about the matter under investigation, how do you know what to ask? And in this area, as quite widely in Africa, people are anxious to please and very ready to agree with any statement the researcher offers which is not totally repugnant to their views (in the latter case they will dodge the question). This is partly from a general desire to please and promote good social relations, partly from a cultural value of hospitality to 'strangers', and partly from a feeling that the researcher - whether outsider or local 'évolué' - is a person of wealth and power who can bring benefits if pleased and cause trouble if dissatisfied.

This is a positive approach for lubricating the wheels of social life, but it becomes a challenge to those of my generation, brought up on a modernist belief in the existence of objective truth and the possibility and desirability of seeking it. We are not necessarily speaking of what the members of the society, or even the fair-minded outsider, would consider lying. If the enquirer is worth any of his or her salt the leading question will not lead in a totally alien direction. But as an instance we may cite the tendency, in this part of Africa, for German and particularly French researchers to report a systematic myth-andritual complex in which the sky is considered a male being who in the rain impregnates the female earth and brings fertility of crops, animals and humans, while sacrifices and offerings at rain-shrines and earth-'groves' are worship offered to the Sky-god and Goddess of the Earth to propitiate them and pronote this fertility-bringing intercourse. I am sure that many people in these areas, if presented with this scenario, would assent to it as a nice idea - indeed orobably many people in the postmodern 'West', those not committed to one of he Abrahamic faiths or to ideological materialism, would do the same. But as we shall see it is noticeable that those who have spent the longest time in the study of individual peoples - Fortes and J. Goody (and, in fact, the present Nriter) - have not found these views expressed as such, unprompted, by the nembers of the relevant societies.

With regards to oral evidence we may in general be more confident that ve can get an insight into something which is emic - an insider view - in the 
society studied from what people do say, rather than from what they can say or are willing to agree to. This of course requires a longer time and greater patience from the researcher; maybe only those privileged to spend a long time in the 'target' area - 'native anthropologists' or those like myself who work in a long-term development project and study anthropology, as it were, on the side, or maybe academics who study a society within easy visiting range of their 'home' institution - will be able to just wait until they hear somebody say something relevant.

1.3.2 Somewhat similar to the contrast between what people do say and what they can (be made to) say is the contrast between what people say they do and what they do do. Again, observation of the more-reliable alternative is frustrated by time pressures, often due to financial constraints but also due to the non-correspondence of the dates available for field study and the occurrence of the behaviour to be studied. [For instance, Drucker Brown's excellent study of Mamprusi royalty (RAMK - see References) is slightly impaired by the fact that the culminating events - the death of a 'King' and the accession of the next - cannot be planned or foreseen and, in fact, took place just after the researcher had come to the end of her fieldwork.]

The comparative objectivity of observations of behaviour is also rendered less valuable, particularly in a semantic field like that presently under discussion. by the fact that one can observe what is done but not why it is done. Again I can only speak for the north of Ghana, but cultural communication piterns hereabouts make "why?" questions particularly ineffective for the purposes for which the apparent equivalent is used in European languages - i.e. obtaining information on motivations and purposes of actions ${ }^{7}$. A possible strategy is to ask what would happen if the activity was omitted, or was done differently. The imagining of hypothetical situations, however, seems to be something more appropriate in some cultures than others, and even where appropriate there may only be some individuals who perform well in such tasks. [Of course part of research design and its implementation is the identification and recruitment of assistants who have some skill at what they are being asked to contribute to the project, but if the task involved is too eccentric to local norms there is the suspicion that one is getting the assistant's idiosyncratic perceptions rather than what is typical of the society.] Also the answer may be too general - the result of any hypothetical omission or alteration of any ritual would be 'very bad'!

1.3.3 We therefore need a response to these weaknesses inherent in the method of research which begins with selecting and employing as reliable an 'informant' as can be found and then asking him (very rarely her) what people customarily do, or what they are being observed to do, and why? In fact the questions (not necessarily to a professional assistant) "What is that?" and "What is / are ... doing?" may very often yield information that might have been expected from a "Why...?" - as linguists know to their cost, as they often may 
elicit lengthy functional explanations when they had hoped for a simple noun or verb. "What is the name of that thing?" is often a better question for obtaining a noun: verbs may be more difficult and the method of eliciting them more language-specific (where nominalisation is possible "What is the name of his / her / your action?" may be possible). One response which may be effective is to combine the methods so as to allow the strengths of one to minimise the weaknesses of another. For example, asking an informant what people normally think, say, or do can be given an objective anchor by starting from an observed non-elicited remark or behaviour, particularly if the assistant also observed it and knows the full context. Detailed transcription of recorded texts in the language/s used by members of the society studied can also yield supplementary insights. To focus on linguistic matters with an assistant who is able to do so can serve to defuse any embarrassment or reserve which might attend direct questioning on such topics. I use 'texts' here in the sense used in field linguistics, referring to any piece of language-use produced spontaneously by speakers of the tongue concerned.

This underlines the need for a multi-pronged approach including listening and everyday observation as well as questioning, recording of explicitly 'ritual texts', and participant observation of explicitly ritual occasions. This extends to questioning about the everyday observation, keeping an eye / ear out to observe in appropriate social contexts whether members actually do and say what informants have claimed, and observance of repeat performances of ritual texts to check whether the version recorded is invariant, typical or aberrant. Then where there are inconsistencies, the researcher has to find very delicate methods of drawing attention to the discrepancies in a way which is non-threatening to the informant (and not disruptive of relations between assistants): if this is possible, attempts to explain the different accounts may be extremely revealing.

1.3.4 In this nexus of interlocking methods, one valuable strand is the structural analysis of relevant areas of vocabulary. Lexicological analysis, particularly in the form of a lexical-field study, has the advantage of working with what people $d o$ say because it is their words which are the immediate object of analysis, and also shares with text study mentioned above (1.3.3) the advantage of removing the focus from behaviour to linguistics which may avoid some of the reserve which informants may feel in answering direct questions on these topics. Thus the analytical work which is a necessary foundation for bilingual or cross-cultural lexicography can also be of assistance in the ethnological understanding of the cultures which are expressed in those languages. From my special perspective I might add that by the study of several culturally-and / or linguistically-related groups comparative and etymological analysis may show up emic clusterings and partitions within lexical / semantic fields as they are preserved across language-change (Naden 1993). As an example, section 2 
of this paper offers the Western Oti / Volta Lexinote (originally Number \#14) on terms in the semantic area in focus here.

1.4 Practical conclusions: In consideration of a particular society's culture and language, we then need to be very careful in our use of terms like 'god', 'deity', 'divinity', 'spirit', so that each word used in the language of description is related in some systematic way to a word or idiom in the language of the members of that society, and ideally the demarcation of topic areas should be justifiable lexicologically and / or in explicit member statements. To give a concrete example, we should not say "in my worldview witchcraft is part of the belief in non-material forces which I label 'Religion' (and don't believe in)", but we examine whether there is any slippage or overlap between vocabulary, personnel, equipment or techniques between the areas of witchcraft and, say, ancestor veneration: if we find none then we do not set up a category of Religion of which these are sub-fields.

It is very difficult to achieve this degree of objectivity: the desirability is beginning to be recognised - McCall says that in considering ancestors "we must discard the boundaries of 'cult' and 'religion'" (1995: 258), but he still slips into terminology like "priestess" and the "spiritual and mundane functions of the shrine" (ibid.: 260 - my emphasis) in his account of Ohafia, without apparent original-language justification (elsewhere he gives local linguistic equivalents for any remotely technical terms). Similarly even Abasi uses "the underworld" (1995: 465) and "the afterlife" (ibid.: 466) in a way which is suspect of deriving from the English in which he is writing rather than the Kasem of which he is writing.

This is not to deny the existence of covert categories in languages, groupings which do not have a lexicalized label but nevertheless are part of the system. [The W.O/V languages characteristically lack lexical terms for any intermediate-level hyperonyms in the taxonomy of natural kinds (Brown 1984, 1986; Rosch et al. 1975). Thus in Mampruli there are syntactic and lexical (both morpho- and semo-) patternings which clearly demarcate a field of colour terminology comprising basic 'black', 'white' and 'red', and derived "yellow" ('dawadawa ${ }^{8}$-powder') and "(blue-)green" ('bean(leaf)water'), but no lexeme for "colour" or "coloured" or "to colour / be coloured / change colour".] If, however, we want to use "supernatural" or some such word to represent such a covert category, then we need to introduce the term by a presentation of the analysis which justifies the usage - and in fact this reasoning will be an important part of the substance of the description. Equally we may wish to use 'Delphically' an English word which is broader in sense than the local-language equivalent; this is valid as long as the precise situation is made clear at the outset. Thus in discussing W.O/V languages we tend to follow the practice of English-speaking members of these societies in using "spirit" to represent the *SII-GA / SI lexeme (1.1 above): this is fine as long as we make clear at the outset that this only refers to the non-material part of a human being, and we do 
not perform sleight-of-hand exposition by slipping "spirit" in with wider reference, where local languages would not use *SII-GA / SI.

\section{W.O/V Vocabulary of Traditional Religion'}

In most of the groups considered here, the influence of world religions is small: my informal estimate is that the number of Christians and serious Muslims (most people follow some Muslim practices sometimes) amongst the Mamprusi is about $10 \%$ each: the remainder follow the traditional religion ${ }^{10}$. Islam may have a somewhat greater hold amongst the Mossi, Wala and Dagomba, but also much less among the Bulsa, Dagaba, Frafra, Hanga (roughly speaking, the Muslim Hanga have hived off as the KaMara - Prost 1974a, Naden MS), Komma, Nabdem and Tallensi; Christianity may be somewhat stronger amongst the Dagaba. The general aspect of traditional religion is similar among all these peoples, as is the vocabulary, though as in other cultural spheres there are distinct variations when one scrutinizes the details.

The foregoing discussion has shown that religion is a difficult area to delimit and that I suspect that much of what appears to Westerners as religion or magic, functions for the members of these societies as science - techriques which one takes on trust from experts and hopes will be effective in dealing with a practical problem ('magic' is what you call the science of people you despise?). The researcher is easily confused by his or her own beliefs and values, both personal and theoretical, or even by connotations and meanings attaching to English vocabulary, and it is very difficult to discover, or even conceive, the best way of expressing in academic, say, English, what a Mampuriga or a Frafra 'really believes' or 'means' by his words or actions in this cultural area. The objective correlates provided by a lexical study of the words used in these areas may, therefore, be particularly beneficial. In a Lexinote it is, of course, the vocabulary which is in focus.

\subsection{Divination}

It is logical to start with divination. The normal procedure in these matters is that one suffers, or fears, some serious problem (infertility or sickness in man or domestic animals, crop failures, drought ...), or one plans some major step (marriage, seeking a chiefship, a business venture...) and consults a diviner (Ghana English 'soothsayer'): the diviner performs his art and then indicates the necessity of making, or obtaining, or making offerings at, one or more of the various cult objects described later.

There are four major lexicalized items in this sub-field, the verb "to divine" (or "consult a diviner"), the name of the practitioner "diviner, soothsayer", the name of his apparatus "diviner's paraphernalia", and a fourth item which may 
have reference to a shrine (other than the actual apparatus), the power / spirit(s) ... which reside in the shrine and / or apparatus and / or guide the divination process, or any combination thereof. If anyone can furnish precise definitions of any of these terms in a particular language-community it would be enormously helpful if they could publish or communicate them.

The clearest, most consistent item in the lists is "to divine", *BUG-:

\section{Vocabulary \#11}

DIVINE, TO:

DB bugi, bagsi; MP bugi; HG bogi; KLA buk / bugid; FR buge; MR boge, bughe; LW (G:MBG) buu / buura; BL bogi, bog gbanta, parese, diiri

The diviner's apparatus is usually carried in a skin bag and "diviner's (or 'divinatory') skin bag" is often used for the whole apparatus, or even (often in MP) for the man himself. I have not observed, nor have I found any detailed description of observation of, the diviner's equipment or methods in the W.O/V-speaking area of Ghana. J. Goody (SOL 97) refers to "the fall of the diviner's cowries"12, and Deschamps (1972) mentions a small stick (baquette). Mossi diviners are said to observe water in a container, pigeons, or an iron 'butterfly' (pilimpika) which is guided by the 'fairies' ( 2.5 below) (Tiendrebeogo and Pageard 1975). Compounds with *BAG are common:

\section{Vocabulary \#2}

DIVINER'S APPARATUS: DB bagri, bagayule "sacrifice ... ancestors" Oppong; MP ba'aksligu / ba'akola, -kona, ba'ayuya (lit. 'names'); KLA ba'akolug / ba'akon; FR baga, bakologo; MR bagh-waogba; BL baan-nyaani (baan -yui "-bag", -yak "-rattle", -doari; gban-doari "wand";

I have followed this order of presentation because in several languages the practitioner himself is called, literally, a 'diviner's bag' or the 'owner' of divination. One would like to postulate a basic "BAG-A / -BA "diviner" (Manessy 1975 reconstructs $\mathrm{O} / \mathrm{V} * \mathrm{BO}$, but forms like $\mathrm{KN}$ ubso can be derived from *BAG - cf. Vocabulary \#10, fn. 19, below - more easily than baga from *BO in the absence of ${ }^{*} b a$ and $\left.{ }^{*} b o g^{13}\right)$. Other items could then be derived from *BAGA; however only in MR (and Rattray's TL) is this the normal surface form:

\section{Vocabulary \#3}

a) DIVINER (1): $\quad$ DB (F) baga / baganima, (Oppong) bagsi; MP ba'akoligu daana; KLA ba'akolug daan, ba'abugud, ba'amaan; TL (R) baga / bagaba, bakologo, (F) baya, (GG) ba'a / 
ba'anam; NB (R) bay, (N) bakulug / bakul; FR baga; MR baga / bagba ("féticheur" - Canu); DR (R) bogubura, (G) bagbuura / bagbuuri; LW (G) bosbuura; BR (K) bosbors; SF baya / bayaba; BL baano / baanba;

b) DIVINER (2): KLA ba'abugud; MR (Yadre) bougesa / bougesanamba; NT booko / boskiba; LB (R) boga; DR (R) bogobura; BL bogroa ("client"); KM buguru / buguti, bugurum;

c) DIVINER (3): $\quad$ KR viisra / viisriba (viisi "examine, scrutinize"); MR geta /getba;

The "diviner's shrine", "divinatory spirit/s", or "divination" terms are not so often cited, and one cannot be sure that these glosses are selected with precision:

Vocabulary \#4

DIVINATION (-SHRINE, -SPIRITS): DB bagtali; TL bayer, bakologo "divinatory ancestors"; MR bagre; LW (G) boo, bay (MBG: 58 "it was repeatedly denied to me that Bagre was an association of diviners"); BL baan-nyaani ("divinatory objects"), jadok-bogluk ("shrine of a spirit that often materializes in an animal ... may become a divinatory shrine")

The "BAG-RI/-A word also appears in "family shrine" ( 2.3 below): it may be that originally the lexeme meant "ancestral spirits (givers of revelation and receivers of sacrifice)", but that gloss is not appropriate to most of the specific terms used in these languages today.

\subsection{Sacrifice: Group Cults}

The next series of items concerns mainly "shrines" which receive sacrifice, mainly to avert actual or potential harm. The languages divide into two main groups according to whether they have a specialized verb "to sacrifice" ${ }^{*} \mathrm{KA}(\mathrm{N}) \mathrm{B}$, or whether they use the ordinary verb which I translate as "to fix" in the American sense of "make or mend" ('fix breakfast / a flat tire'). The former focusses on the killing of the animal; the latter has as its grammatical object, normally, the shrine at which the offering is made, and includes the whole ceremony (libation, prayer, preliminary killing of chicks, actual sacrifice, butchering and distribution of meat). Thus one might say MP $\mathbf{N}$ ya m-maali $\mathbf{m}$ ba'ari, "I am going to make an offering at ('fix up') my ancestor-shrine"; at a funeral it 
is announced that so-and-so is giving, for example, a sheep m-maali $\mathbf{u}$ ba "to 'fix up' his father" (or whatever relation the deceased was), though it is also common to say n-ti (u ba) "to give" which may be simply "for...". The same verb is used for any ceremony: Mamprusi greet Ni i soosa maaligu, "For your yes. terday's 'fix-up"', as a greeting on the day after the person saluted was involved $^{14}$ in any ceremony, dance, festival, etc., whether he or anyone else made a sacrifice or not.

\section{Vocabulary \#5}

a) SACRIFICE, TO (1): "KLA (? kanb "to singe"?); TL kaab; FR kaanbe; (? cf. MP ka "to bless, pray" = FR kan' [n. kan'an]; LW kaab [n. kan'an]; LW kaab [n. and v.]?)

b) SACRIFICE, TO (2): DR (H) bug, (K) boys, (G) bagre; LW (G) bsore (bosre = DR bagre "initiation rites of a secret society" — SOL: 52); $B R(K)$ boวr

c) SACRIFICE, TO (3); DB mali, [n.] malgu; MP maali / maanni], [n.] maaligu; HG maali; KLA maal, [agent n.] maan / maana; MR mane, [n.] maoongo;

The "MAL 'fix' root occurs elsewhere without being said to be used for "sacrifice":

c') 'FIX' ( $\neq$ SACRIFICE): KR maali; TL maali; NB maane; FR maale; NT mani; DR mal;

d) sara in DB / MP (also Bisa - so maybe in MR and KLA as well) is a funeral sacrifice (and accompanying ceremonies); it is said to be from Hausa - ? sense "cut" or "custom"?

\subsubsection{Public Sacrifice: the Earth}

Under "land" in Lexinote \#7 there is a discussion of the land in its 'religious' aspects, listing "Earth-Priest" and "Earth-Shrine, grove". The relevant items are repeated below: 
Vocabulary \#6

GROVE, EARTH-SHRINE: DB (FS) tipgban (-dana); MP tingbanni / tingbana; KR (P) temgbaõ; TL tungban, tongban; NB tengbonu; FR tengono / tengono, (Rapp) tenganne / tengana ("sacred grove"); Tengongo Earth-Goddess", tenkuggere / tenkuga ("on which the Tendaana makes offerings"); MR tepa, tenkuga ("sacrifice place"); DG tigan, tẽgan; DR tingan; LW tengaan; BR (K) tẽgan; BL tanggbain / tanggbana ("earth-shrine [n.]; spirit of the earth; earth-shrine; sacred place of the earth-divinity ...")

This word is a compound of "TIN-/TEN-, with a range of meanings in the area of "earth, ground, down; land, soil, sand; country, town, village" (Lexinote \#7), and "GBAN- of which the meaning "skin" is presumably basic, with derivatives "leather, leatherwork" and "flat things - paper (> letter > book), sheet of (various things)". It is only distinguished, if at all, by nominal declension from "region, country, piece of land" - e.g. MP tingbanni / tingbana "grove" I tingbannu / tingbana "region".

As to the personification of the Earth, Franz Kröger (p.c.) describes being told that a certain Buli tengbani could not receive sacrifices in the aftemoon as 'he is not at home now'; and Patrick Adongo (p.c.) mentions a Frafra saying, when a squall of rain is seen passing, that the tengons is going on a visit and cloaks himself in the storm'. For DG Pénou-Achille (1982: 70) translates tigan as "dieu de la terre"; for LW, J. Goody quotes of the tengaan that "he (o) loves people", and as a female derives fertility from sleeping with the male sky (saalo) - though in a fn. he cautions "I do not wish to suggest it is a recurrent theme in LoWiili speech, but it appears in the origin myth which I recorded". For DR / WL Tuurey (1982: 16) speaks of "tutelary spirits, the chief among them being a female earth deity known as Tenge \... The tenge has many tengbama (shrines)". In the case of MR we are told that (Somé 1970: 9) "the Earth (Tenga) is considered as the wife of the heavens ... has an altar of sacrifice called Teng kuga"15. Rapp (1966) gives for FR tenga "earth...", Tenga "Earth-goddess", tengongo "Earth-goddess, wife of the sky-god Yinne"15.

In . TL, however, although Fortes mentions that "the Earth is commonly referred to by the third person singular pronoun $\mathbf{u}^{\prime \prime}$ (i.e. the personal pronoun, not inanimate ka as for common noun "earth" - see Naden 1982), he states that "there is no convincing evidence for the Earth being personified as a 'Goddess' in the Northem Territories of the Gold Coast - certainly not among the Tallensi" (1945: 175, fn.), and this seems correct for at least MP, DB, KL and HG. The 'earth-as-wife-of-sky' motif therefore seems to correlate within W.O/V with.just the linguistic subgroup Northwestern - MR, FR and the DR-group, though Zwernemann (1961) cites the concept from Southwest Grusi (Sissala 
etc.) and Kasem-Nuni, so perhaps a geographical East / West division is in question.

Somé (ibid.) also says for MR that the country is dotted with "sacred groves inhabited by good spirits which protect man. These spirits are embodied in (matérialisés par) animals (snakes, crocodiles etc.)"15, with which we may compare the statement quoted by DruckerBrown (RAMK: 100) from the daughter of the Mamprusi earth-priest chief of Gambaga: "Gambaraana has earth-shrines. They are all chiefs. They are not human beings but snakes ... They aren't people of this world ... They just help to guard the world." In the neighbouring Kasem region (north of BL, west of FR, south of MR - their language is Gur but of the (Northern) Grusi subgroup, Naden 1989) "The tangone is a spirit which inhabits a grove of trees near the Kalogo stream, but the term seems to be used both of the spirit and of the grove indiscriminately." (Teviu / Callow n.d.: $85 \mathrm{fn}$.) - cf. FR Adongo 'the tengono is the trees etc.'.

While a diviner can in a specific case prescribe practically any course of action, including an earth-sacrifice, it is in general true that the earth-shrine is the concern of the residents (or descendants of one-time residents) of the stretch of earth, the 'parish' (Fortes, J. Goody), covered by the particular shrine.

Fortes, however, describes a kind of 'public' shrine which he calls the "External boyar"; unfortunately he never indicates what the TL translated "External" is, or whether the Tallensi do not themselves make the distinction, but it rather arises from the anthropologist's own analysis. This shrine receives sacrifices not only from all Taleland but also from outsiders from other parts of Ghana who come to ask its help, particularly in cases of childlessness. Certainly the Earth-shrine serves a wider 'congregation' than the other shrines, and it is the 'groves' which are primarily the locus of any sacrifices not called forth by crises in the life of an individual or a family but conducted at regular seasonal intervals, such as the 'beer of the grove' tengaan dãa pre-farming-season rogation sacrifice of the LoWiili (SOL: 92 - "the annual sacrifice at the earth-shrine"), and among the Tallensi the comparable Golib (Fortes 1945: 104) and the 'beer of the shrine' (Boyaraam ibid.). Comparable regular festivals seem less common' elsewhere (Naden [ed.] forthc.), though it is hazardous to argue from silence in existing reports: the Bulsa have a great Harvest Festival called the Fiok, for instance, but it is sufficiently independent of the 'ancestor worship' complex not to require mention in Kröger 1982. Remarkably for an agricultural people, there is certainly no annual seasonal festival amongst the Mamprusi: all their festivals are based on the (non-seasonal) lunar calendar (Naden forthc.), and the Dagomba, at least, are presumably the same. In Zuarungu the Frafras refer to festivals of other peoples (TL, NB) as one form of seasonal reference (Schaefer / Adongo forthc.) so presumably do not have comparable festivals of their own, nor do the Kusaas seem to have prominent seasonal rituals. Both Fortes (1945: 104 ff.) and J. Goody (SOL: 92) note that the rogation festival outranks the harvest celebration. 
The 'grove' of the Bulsa sounds much more of a family possession than a 'public' shrine in the discussion of Kröger 1982, but this may be because of the particular focus of that work.

Sacrifices at the 'grove' are determined and led by the "earthpriest", 'owner of the earth(-shrine):

\section{Vocabulary \#7}

'EARTH-PRIEST': $\quad$ DB tindana; NN (Sk) tindaana; MP / KR (N) tindaana / tindaandima; $\mathrm{KR}(\mathrm{P})$ tembaõdaane / -daamba; KLA tendaan; NB tindaan / -daannam; TL tendaan / -daannam; FR tendana / -daama; NK (R) tendana; $\mathrm{DR}(\mathrm{R})$ tendagena, (H) tindapna; MR tensoba; LB (R) tensob; BR tengaanssb; SF tinəsuba; BL tennyono I -nyam; KM (South) tintion (=Sisaala); KM (North) tindaana $(=\mathrm{MP})$

The customary glossing of this as 'Earthpriest' is based on the reasoning: 'kills animals and speaks to the earth(S-shrine), this is sacrifice and prayer, that is religion (therefore not real) - a religious functionary is a priest'. The form is TIN- / TEN- as above, plus the item which is semantically the same though formally different in the various languages, and is glossed by English-speakers as 'owner'. This latter form has a meaning / usage similar to the Arabic dhu and Hausa mai: it is a person (human or personification) related to, or defined or distinguished by, something which is characterisable by a noun - either a 'person, place or thing' or a grammatical nominalization. This may be used in a context like Zupiliga daana! "Hey, you with the hat!" (all these examples are MP); and often refers to a hawker of some particular item - Koddu daana be ni? "Is there a banana-seller around?" / Koddu daana! "Hey, banana girl!". It is semantically, though not formally (unless in the Northwestern *SOB-seen in $M R, L B, B R, S F$ in Vocabulary \#7) related to a verb *SU which means to be 'in charge' of something ('again often glossed 'to own') both in the sense of having privilege over and of having responsibility for it. Hence joni n su kuuri wa? "Who 'owns' this hoe?" may imply "... if it's his we must give it back to him" or "... I'm going to give him what for - leaving it here for me to trip over!". The person 'in charge' of it in this sense is its daana (soba, nyono) - not "owner" in the legal sense (words like MP dinni "own thing" and toori "very own" carry this meaning), the person concerned may have borrowed the hoe, but he is currently responsible for it. At the other extreme Daana is used in the titles of senior elders at major chiefly courts - KpanaRaana, WudDaana (literally 'Horse.Owner', 'Spear.Owner') - and chiefly titles, GbanDaana being the chief of Gbanni, and so on. The chief does not have feudal or autocratic 'ownership' of the village, but has both privileges and responsibilities in regard to it (see 
also Naden [ed.] 1984: 4f.). This would seem to be applicable in general to the relationship between the Tindaana and the Earth.

Mamprusi tindaandima are not typical - they may be priest-chiefs with ritual functions vis-à-vis the 'King' (Drucker Brown 1975: 92-3), may also divine (94), and may have special functions like neutralising witchcraft ( 2.5 below) or operating an oath-verifying ordeal, rather than being primarily responsible for a specific piece of land. Conversely there are many places in Mampurugu which do not belong to any earth-'parish' jurisdiction.

\subsubsection{Family Sacrifices}

The ancestor sacrifices par excellence are those offered at clan or family shrines. These are 'public' in the sense that they concern all those in the relevant genealogical grouping: they are 'private' in the sense that there is a defined group and outsiders have no part in them. The senior male of the relevant group is the custodian and person responsible for the cult, but it is not his property, and he is under pressure to maintain the ritual correctly, both from family members and from society, especially manifested through the diviners and the ill-luck which leads people to consult them ('society' includes both the living and the dead, the latter being specially interested and potent in this area of life). The sacrifice is made to particular (deceased) ancestors: there is usually no lexical difference between "ancestor" and "grandparent":

\section{Vocabulary \#8}

a) GRANDPARENT, ANCESTOR (1): DB yaba / yanima; MP yaaba / yaadima; HG yaa(ba) / yaadima; $K R(P)$ yargo / yargodima; KLA yaab / yaanam; TL yaab / yaanam; NB (R) yab(a); FR soyaaba / soyaabdoma; MR yaba / yabramba;

b) GRANDPARENT, ANCESTOR (2): FR soyaaba / soyaabdoma; NT cakotuwo / cakoto; LB (R) sakum; DR (R) sankuma, (G) sããkum / sããkumine; WL (R) sankuma;

c) GRANDPARENT, ANCESTOR (3): KLA ba'ar / bada "ancestral spirits" (S); NT cakotuwo / cakoto; DR (G) kpiin ("the dead"); BL kokpieng / kokpiengsa, /koba, chue, ngiak / ngaasa, kpilima ("the dead") 
The rendering (Arozenara: 1975) 'Mânes des Ancêtres' - "ancestral spirits, shades" reads too much connotation into the term. No word which would be rendered "spirit" is used in the local languages for any of these phenomena. Note Kröger, 1982: 6:

... we must find out to which aspect of the ancestor's personality a sacrifice is offered. It is not offered to his body, nor to his soul ... All sacrifices are offered to the ancestor's wen which has never been inside a living person.

The negative part of this is true throughout the area; the positive idea that the sacrifices are to the 'god' (2.3.1 below) is, as far as I know, only BL. The importation of terms like 'spirit' ('ghost', 'shade' ...) into this discourse reflects the Western dichotomy between the living and the dead, the material and the immaterial, the natural and the supernatural. A speaker of one of these languages simply says, for instance, "I am going to give water to my grandfather", and there is no linguistic distinction between giving a living old man a drink and pouring a libation to a deceased ancestor.

Although the words spoken during the rituals are directed to ancestors, one normally talks about "sacrificing to / 'fixing up' the shrine". Thus if a Mamprusi says $\mathbf{N}$ ya maali $\mathbf{m}$ ba'ari, this can mean "I am going to sacrifice to my ancestors" or "l am going to repair (the physical structure of) my ancestor-shrine". I witnessed the maali -ing of a ba'ari where the sacrifice was made in the middle of the entrance yard of the Paramount Chief's palace, where there was no form of physical 'shrine' or 'altar' at all: by eighteen hours later the blood, feathers, and millet flour placed on the ground as a gift for the ancestors had been trampled and scattered so that no sign of the sacrifice remained. Most commonly, however, the shrine is - or is contained in ${ }^{16}$ - a hump, dome, cylinder or column of clay or gravel. In addition to its use for 'shrines' or 'altars', this same physical form of construction may be used to make a place for sitting or putting things on (a low, domed, 'earth-bench' and a cylindrical clay 'occasional table' are usually to the right and left of the doorway, just inside, as you enter a Mamprusi woman's room - the door is hinged on the left so that it reveals the seat for you to sit and greet the occupant, while concealing the property on the 'table'). It may also be used to form a larger 'dais' for a chief or elder to sit on:

\section{Vocabulary \#9}

EARTH-BENCH, DAIS, ALTAR: DB bimbini / bimbina; MP bimbinni / bimbina; KLA bimbim / bimbima; TL bimbimər; FR bimbine / bimbina; 
However, the term for "shrine" is usually used for the physical structure as well as the ritual function: it may be noted in passing that in general, while not in use, the shrine is not specially 'holy', there is no sacrilege involved in touching it, and so on ${ }^{17}$. The MP shrines are often minimal - either nothing, or a low hump; BL mediumhigh, often cylindrical or domed (also TL, KL) or conical (TL): the FR pillar-shaped, tall cones. While anthropologists often leap to assigning such shapes 'phallic' significance, I am not aware of any such associations being expressed by members of the societies. Other physical forms include clay pots (BL, FR, KL, TL), and pots, stones, etc. supported by a branching stick (0.5-1.0 mtr. high) - MP, TL. While in MP and many of the other languages there is a different term for each functional type of shrine, the BL word bogluk seems to have been generalized to function very much as I am using 'shrine' - you can have; for instance, a wen-bogluk ("god'-shrine" - MP "wun-bugri - ba'ari would be impossible), a tiim-bogluk ("'medicine'-shrine" - see 2.4 below) and so on. Similarly in FR bagre can be "anything you sacrifice to (including a talisman or drum)" (Nancy Schaefer, p.c.).

\section{Vocabulary \#10}

a) FAMILY SHRINE (1): MP ba'ari / ba'a; HG begiri; KLA ba'ar / ba'a; TL (GG) ba'ar / ba'a, (F) bayer / baya ("the generic term for any ancestor or medicine shrine" 1945: 52); NB ba'ar / ba'a; FR bagre / baga, bakologo / bakon; DR bagre'18; LW (SOL) bosre 19 (cf. BL ma-bage of an ancestress: "bage is always a sacred horn" Kröger 1982: 2);

b) FAMILY SHRINE (2): DB (FS) bugule / buga; KLA bugur ("you go and get it from your mother's people" - S. Agumah p.c); TL boyar / boga; DR bosre; BL bogluk / bogluta ${ }^{20}$;

Only the Dagaba seem to have human effigies (kpiin-, sãã-daa "ancestors' stick") of the ancestors (SOL: 88). The existence of secret societies is only noted, in W.O/V, for DR and MR, masking only in MR - in northern Ghana the only other groups with masking are the DR-contiguous Grusi groups Tampulma and Vagla; note also that the sexual union of sky and earth is a DR-MR-FR subgroup concept, 2.2.2 above. Shrines for family ancestor cults seem to be located at the interface between the house interior and the outside world, just within, or on the outside flanking, the gateway of the rooms-and-courtyard house of the eastern area (Naden [ed.] 1976: 35, and Map 2.c, 33), in the cattle-room or 'byre' which is the only room in the western fortress-style house which communicates with the outside (J. Goody SOI: passim; plan p. 39 - note how the "medicine shrines" room connects to the interior of the house, the 'byre' outwards) — normal access being by ladder over wall or roof. 


\subsection{Sacrifice: Personal Cults}

2.3.1 The sacrifices so far considered have concerned groups - people of a given 'Earth Parish', or all members of a clan, family, or other genealogically-defined segment. There are also shrines which are the personal concern of an individual. One of these is the 'god" -"WIN / WUN / YIN: "each person's Yin belongs uniquely to that person. It is a symbol of his individuality" ... "his personal Destiny" (Fortes, 1949: 227). Only in BL is the 'god' of an ancestor described as continuing to receive sacrifices from descendants (quote, 2.2 .3 above), bogluk and wen seeming to be used almost indiscriminately in the naming of BL shrines (Kröger 1982: passim, e.g. pp. 16ff.).

The Bulsa wen (a stone) comes from the sun to every (?) person, "usually during childhood"; amongst the Mamprusi only some people have wuna, which are clay pots or other objects, made for them in infancy. In contrast, the TL yin comes, normally, from the bush, and usually to a young man, in the form of an animal he hunts, or a found object, often a piece of metal, perhaps a tool or weapon. The diviner reveals that there is a specific group of ancestors who "demand that he should accept them as his Yin and sacrifice to them on this shrine" (1949: 228); in KL the 'god' may derive either from the father's or the mother's clan and seems to function mainly in terms of preventing the person from doing something important (e.g. marriage) until it is propitiated (S. Agumah, p.c.). Fisch (1913) describes DB wune as "object of idolatrous worship in the house, made of clay: household idol"15 (but see in 2.3 .3 below). The vocabulary, originally in Lexinote \#3 'Sun and God', is updated as:

\section{Vocabulary \#11}

a) GOD: $\quad$ DB wuni / wuna; MP wunni / wuna; HG wunni / wuna; KLA win / wina; TL yin; NB yin / yina; FR yeni / yena; MR wendi, winde; NT wenne; DG wen; LW wen; SF "God" (Naa)wuni; BL won, wen; BM yenu;

b) GOD (2): $\quad$ MR (R) nwendi; DG mwin; DR pmin; WL ngmini; M pmin;

\subsubsection{Spirit-Guardian}

A very similar concept seems to be that of 'spirit-guardian'. This tends to be defined as something like "any 'religious' power which takes a particular interest in an individual". In LoWiili this "tutelary or guardian spirit" may be "special guardianship of the ancestors" for an individual or clan, or may be the Earth or any of the other shrines: it is usually associated with a special place 
(the tutelary of one section 'is' a baobab tree) - SOL: $63,50,99,76$. The BL guardian spirit always has a man-made shrine: usually it is one of the household gods (e.g. an ancestor, a jadok, a medicine, or a tenggbani) - Franz Kröger p.c. It is the father who entrusts the child to its spirit-guardian which is often his (the father's) Yin - TL (Fortes 1949: 165, 212, 229), and in KL they name the child after it and then he has to sacrifice to it, "it can be from his grandfather, so it would be a stone", it may be in a room or 'by' a room in a bimbim (Vocabulary \#9).

\section{Vocabulary \#12}

SPIRIT-GUARDIAN: DB sugri / suga; MP sigri / siga; KLA sigir / siga; KLT (R) segri / sega; TL seyor; NK (R) segere / sega; MR (siga "pierres de sacrifice" - Canu); LW (J. Goody) sigra; LB ( $R$ ) sera / sega; $D R(R)$ segera, (G) sigra; DR siura ${ }^{21}$ ("LoDagaba" - J. Goody); BL segi / sega;

Unfortunately this item does not appear on the wordlists of the linguists: most of the attestations not from the well-founded anthropological studies of Fortes and J. Goody are from the dubiously reliable Rattray. In DB and MP the term is used in personal names - (Na-)Sugri (Na-)Sigri; for DB this is said to be connected with identification with a reincarnated ancestor, and this may be also the case for MP though I was told that the etymology is rather from sigri / siga "first rains". The MP wunni (Wunni also used as a personal name, like Sugri it may be used for man or woman) fills more of the function attributed to the *SIG-RI elsewhere.

\subsubsection{Personal shrine}

In MP the family ba'ari (2.2.3 Vocabulary \#10 above) is clearly distinct from the bugri, the concern of an individual, which he may obtain for himself, or else it may be inherited, or obtained for him / her at birth or in childhood (the details of this need checking) especially if his / her sickliness or the death of previous children should cast doubt on his / her viability (the child, of either sex, may then be named Bugri, and in that case may receive a 'proper' name later, at a safe age like 9-12 years). One significant objective criterion of the distinction in MP is that sheep are the only 'small cattle' acceptable as a sacrifice to a ba'ari, while the bugri receives goats. Thus Drucker Brown quotes the Gambaraana as sacrificing goats and fowls "and make ba-yu-bug-shia" (RAMC: 94): "make" here is presumably maali "sacrifice (to)" (Vocabulary \#5.c above); bayubugri would be a bugri of the name(s) of father(s) ${ }^{22}-$ only a noun like bugri can be compounded (in its root form) with the indefinite -seaa ('shia'), not the verb 
m-bugi "to divine" (Vocabulary \#1 above) as implied by Drucker Brown's translation "sacrifice to the ancestors indicated by divination".

In its individual nature the MP bugri seems to share some of the functions of the *WEN and the *SIG (2.3.1-2 above). It is also used of a few 'public' shrines, such as that at Bugiya $8 \mathrm{~km}$ ESE of Walewale which enforces oaths and is particularly used in finding stolen property, and its oath as an ordeal for suspected thieves: this usage seems comparable to Fortes' "External boyar". The KL bugir may particularly be something you "go and get from your mother's people" (Agumah p.c.) for yourself or your child. The clear lines drawn in MP do not seem to be general for the group: the root, presumably, appears in "to divine" (Vocabulary \#1) and in some words for "family shrine" (\#lO.b). The BL cognate is, as we have seen, a general term for 'shrine', and the TL one refers to a public or clan shrine. Fisch, for DB glosses "divinity (Gottheit), a spirit worshipped in some kind of object" (op.cit. ${ }^{15}$ ) and gives quotations that the tindana looks after the bugule, it is a:stone or trees, at night he walks about, he kills people, he lives in the bush, he is a 'fairy' ( 2.5 below). This sounds confused: Christian missionary Fisch with Muslim language-helpers (he adds in this entry "My informant's statement is influenced by Islam") tends to give a jaundiced view of traditional religion as already seen in 2.3.1 (a DB quotation in the entry for tingbandana includes the words "he is a bad man"): however it may show a generalisation of the term to include the 'grove' and other shrines (or show that the MP specialisation is a recent innovation).

\section{Vocabulary \#13}

SHRINE:

$\mathrm{DB}$ bugli / buga ${ }^{23}$; NN (Sk) bogole (tindaana sacrifices to it); MP bugri / buga; HG bugiri / buga; KLA bugir / buga (matrilineal); TL boyar / boya ${ }^{23}$; NB bugur / buga, wook / woot ${ }^{24}$; FR bugure ${ }^{23}$ ("shrine-spirit"), bagare / baga 23; MR bugli; DR (H) bog, bogr / bogo; BL bogluk / bogluta ${ }^{23}$; $\mathrm{KM}$ bo-/ buguli, buguti;

\subsection{Acquired 'Power'}

This division may seem arbitrary, but there appears certainly to be a clear distinction between all the foregoing shrines and those to which we come now. The former are treated, as it were, as existing in their own right and laying the obligation to cultivate them upon the person / group concerned (cf., e.g., Kröger "if the tengbain spirit has no bogluk, i.e. if he does not receive any sacrifices, he may cause harm to human beings" (1982: 85); and Fortes on the TL Yin quoted in 2.3.1 above). The latter look towards powers or forces which individuals set out to acquire in order to fend off existing or feared misfortune, to 
gain strength for a venture, or to attack an enemy. Normally the acquisition of these objects involves going to a practitioner and purchasing them, often as a straight commercial transaction, or by providing an animal whose slaughter may in some sense be a sacrifice and a source of power, but of which the practitioner keeps the meat as (part of) his fee, and parts of the animal - horns, bones, skin, blood ... - may be used in making the object. The general term in this area is 'medicine' - a very ancient lexical root probably related to "tree" 25.

\section{Vocabulary \#14}

a) MEDICINE: $\quad$ DB tiim / tiima; MP tiim / tiima; $H G$ tiim / tiima; $\mathrm{KR}(\mathrm{N})$ tiim / tiima, $(\mathrm{P})$ tinse "un remède"; KLA tiim / tiima; NB tiim / tiima; FR tiim; MR tiim / tiito, -tibo / -tido; NT tiem; LW (G) fil, tiib / tibe ("medicine shrine"), -tiib / -tibe, - fĩi; $B R(K)$ satẽe ("medicine to treat someone struck by lightning"); SF tiim; BL tiim / tiita; KM tiim / tiiti;

The expert who has the power to make and dispense medicines of this type is a "medicine-man" (lit. '-owner')

b) MEDICINE-MAN: DB (N) tiimalana, (FS) timlaana / timlaanema; KLA tiimadaan; MP tiindaana, tiimadana; MR tiimsoba I tiimdamba; BL tiimnyono / tiimnyam; BR (K) gyebors;

As the translation suggests, a frequent reason for seeking such power is to cure a disease, and the verb "to heal, cure" is related:

c) HEAL, CURE: DB / MP / HG tibi; KLA ti'eb; KLI tieb; FR tebe; BL tebi (TL tiba, FR teba "medicine-man")

As something purchased from an expert, "TII-M covers both 'magic' medicines and modern, pharmaceutical medicines. The modern practitioner is usually distinguished by being described by a form from English "doctor". There is additionally, certainly in some of the languages, a term for herbal medicines, which anyone can go to the bush and find and prepare for themselves. The form is usually etymologically "tree-roots"26, though in fact it is more often bark and leaves which are used:

\section{Vocabulary \#15}

HERBAL MEDICINE: MP danya'a; KLA danya'a; FR don'onrs; DR daanyuur; 
Medicine' represents such a wide spectrum of powers, offensive and defensive, healing and protecting, that the term 'overflows' to other parts of the field. Fisch quotes statements that the tindana has much medicine (but he also confuses tindana and timlana etymologically), the Muslims also have a little, and so do witches ( 2.5 below). Jack Goody speaks of a clan which "owns the rain because of its powerful rain medicine" (SOL: 80), hunting medicines (including wefî "bush (hunters') medicine", see Lexinote \#8), newhouse and clan shrines (yipaala tiib, dosrs tiib). 'Medicines' are often contained in pots (MR tiimruko "jarre sacrée contenant des produits mystérieux": BL (tiim-)bogluk "often a clay pot filled with medicine") but are also wrapped in skins, ropes and / or pieces of paper / plastic and hung up in or on rooms or granaries, or as skulls, horns or sticks of various forms thrust into the thatch or the space between the thatch and the top of the wall. The word is also used for modern "chemicals", especially insecticides but also the chemicals used in photographic processing and similar procedures.

Perhaps to be treated as a major subcategory of 'medicines' are talismans and amulets. These are certainly etically and objectively distinguishable as they are carried or worn about the person - on necklaces, bracelets, rings or attached to clothing - rather than being in a fixed location. All the other objects mentioned are installed in a specific place, though they may occasionally be transferred, for instance when a house is abandoned and built elsewhere; there do not seem to be any ritual objects which are periodically moved as part of their use - spending part of the year in one place and part in another, for instance, or being taken in procession as part of the rite (except, perhaps, the spears and other objects, including the 'King' - RAMK: 156 foot, used in MP etc. kingship rituals - RAMK 58-59, 96). These and other medicines may have many different specific names according to their particular purpose, manner of acting, or ingredients (e.g. FR iila "horns", ligiri "cowries" etc.; MR tiimnugbinsi "magic rings"). General terms are not widely recorded information please!

\section{Vocabulary \#16}

AMULET, TALISMAN: DB sabli / saba; MP sabri, sabli / saba; FR bagri / baga; MR sebere/seba; WL/seba; BL bage / baga, poali I poala;

In general a medicine or amulet does not receive any cult; having been acquired it just does its work. However, anything of special significance may receive a sacrifice - musical instruments (MR - Arozenara; BR Steve Batstone, p.c.) especially drums (FR Nancy Schaefer, p.c.) and talismans (FR ibid.), medicines, blacksmith tools, and so on. Some medicines may thus be 'topped up' to restore 
their power, but many dusty, cobweb-covered 'medicines' hang in rooms from year to year without any apparent attention being paid to them.

\section{5. 'Fairies', Witches}

Two other major concepts seem to outsiders to be relevant to this semantic area, though they may not be emically 'the same sort of thing' to local members. The first is labelled in the local English by the English term 'fairy', and this is a convenient label as the alternatives are cumbersome and do not fit the variety of concepts which are attached to what is evidently a cognate set of terms in the languages. The other is universally labelled with the English term 'witchcraft' though the African concepts are at least as far distant from any original English sense of the word as in the case of 'fairy'.

\subsection{1 'Fairy'.}

The personages usually described in Ghana English as 'fairies' are in most cases mischievous bush-sprites - little men with red hair and beards, with feet on back-to-front so that their footprints mislead trackers. They encounter lone people in the bush and disorient them so that they are not found until some time later, and maybe some distance away, dead, mad or temporarily dazed and amnesiac. However in LoWiili they are "hill and river sprites" (SOL: 38: also "bearded dwarfs" p. 91) who may receive sacrifices and may be an individual's spirit-guardian (2.3.2 above). In MR they may also receive sacrifice (Some 1970: 10) and guide one form of divination (2.1 above). Mendonsa (1973, 1982) mentions a new and marginal 'fairy'-based divination for the Sisaala, a Grusi group living between the Bulsa and the Dagaari peoples. Fisch was told by his informant of the bugele that was cared for by a tindana that "he is in the bush, he is a fairy" (translated by Fisch as 'a Devil, evil being'). The word seems particularly prone to phonological variations while remaining recognisably the same lexical item:

\section{Vocabulary \#17}

FAIRY:

DB kulkparga / kulkparsi, (N) kpilkparga / kpilkparsi; MP (east) ku(r)kpaariga / -kpaarisi, (west) kpikpaariga; HG kikpaarigu / kikpaarigusi; KLA kikirig / kikiris; TL kolkpaareg / kolkpaaris; FR kenkirego / kenkito; NK (R) kyinkyirega; MR kinkiriga / kinkirisi; LB (R) kınton; DR (K) konton; LW (G) kıntımo / kontome; BL kikiruk / kiki(r)ta, kikerik / kikerisa; 


\subsubsection{Witchcraft}

Witchcraft is a sphere which is certainly not emically linked to the other notions: only to outsiders does it seem to belong in the same category, as involving powers and happenings which are not explained in his materialistic terms and are regarded by him as 'supernatural' or 'spiritual' (and therefore unreal).

When someone unexpectedly gets sick or dies, one explanation which may be given by divination ${ }^{27}$ is that witchcraft is responsible. The diviner or public opinion points to somebody as the witch - usually a woman, often an elderly relative or household-member: if the suspect does not confess, there may be a witch-finder who can 'see' and indicate the culprit. The witch confesses and / or is 'shamed' by being beaten and howled at (MP n-wooli - "to go 'Woo, woo!' at somebody") by a circle of villagers. The witch is held to have 'chewed" the 'spirits' (MP siiya / siisi) of people, trapping them with some apparatus or 'flying' to batten on them at night, and the victims though outwardly unaffected may then sicken and die.

The witch is usually compelled by ostracism if not force to leave the house and village. In MP the chief of Gambaga has 'medicine' which neutralizes witchcraft, so he has a quarter in his town which forms a 'city of refuge' where accused witches can live unmolested. The whole preceding account is MP, but probably the same is true in outline for the whole area (cf. the essentially similar account for TL - Fortes 1949: 32ff.). Though Fisch quotes "a witch has tim and casts enchantments" there is no evidence that anyone actually consciously practises witchcraft (in contrast to, e.g., the Tiv), and it is sometimes treated more as a dangerous disease which infects the witch than a culpable offence.

The form is *SO-, in Noun Class I for the witch as a person; I cannot explain the nasal which is present between the root and suffix in some languages, particularly in $\mathrm{DB}$ and $\mathrm{MP}$ where it is only in the singular:

\section{Vocabulary \#18}

WITCH:

DB sonya / soba; MP sonya / sooba; HG sonye / sonyesi; KLA soenn/soonb; TL soi / soob; FR sonya / somba (R) soa / soba; MR swoya / sweeba; LW sosr; BR (K) sosba (? = pl. ?); BL sakpak, (lam-)yiik / yiisa, nyaaroa / nyaaroaba "seer";

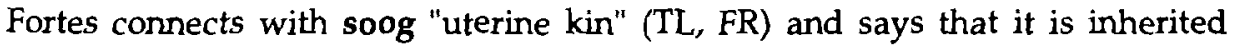
matrilineally, which is not the case in MP, at least. 


\subsection{Conclusion}

Note the two roots cropping up throughout this semantic field:

*BAG: Vocabularies 1, 2, 3.a, 4, 5.b, 8.c, 10.a. 13, 16

*BUG: Vocabularies 1, 3.b, 4, 5.b, 10.b, 13

\section{Notes}

1 The Lexinotes project is described in Naden 1993.

2 It might be urged that the established ethnographic practice of concentrating on 'traditional' cultures is both patronising and irrelevant in the modern world. However, most people outside major cities are living nowadays in a cultural continuum which blends the traditional and the 'modern', and it is valuable to have analyses of the traditional component in order to study the blends, this being the more difficult both to isolate and to understand.

3 The whole dictionary was published in the same year as the translation of Otto, though the "Religion" article was in a fascicle published in 1906.

4 This is clearly consistent with the finding that "Bantu terms used to refer to ancestors were identical to those used to denote living elders" (Kopytoff, 1971 apud McCall 1995: 256).

5 With regard to ritual matters, at least; for secrecy in historical traditions see Davis 1992: 67-8.

6 The lengthy cosmogonic and cosmological text from the Bagre, and its related ritual, recorded by J. Goody (MBG -- see References) is very untypical for the north of Ghana, let alone the Oti / Volta groups; one wonders whether it is evidence for a westward-looking stance, influenced by Lobi and Senufo peoples.

7 On cultural specificity of the function of questioning see Esther Goody, 1978. In Mampruli and its congeners "Why do / did you...?" is functionally 'Why the Hell do / did you...?' - i.e. a rebuke rather than a request for information.

8 The sweet yellow powder surrounding the seeds in the pods of the Parkia tree (P. biglabasa or $P$. Clappertonia), a species of which many parts are put to various economic uses (French nérê).

9 This section is largely based on Lexinotes (see Naden 1993) numbers 3 "Sun and God" and 14 "Traditional Religion". The Lexinotes \#3 ("god / God") and 7 (section on "earth-priest", "grove") sparked off an epistolary discussion between myself and (particularly) Franz Kröger as to how far one can rightly speak of "deities", "spirits" or "supernatural beings" (rather than "(non-material) powers, forces") in connection with many of these areas. Some of the discussion and data used here arises from this.

10 Now see also Barker 1986.

11 Vocabularies re-edited June 1993.

12 Wumbillah ( $\dot{n} / d$ ) notes for Kusaas that a cowri that falls mouth-up is said to 'smile', and combinations of smiling and non-smiling outcomes in the fall of three or four cowris have significance as responses to the diviner's or client's questions.

13 But see Vocabulary \#3.b entries.

14 Or greet Ni ti ... "For our ..." if the greeter was also involved. 
My translation.

'Contained in' in cases where the actual sacred object is a stone or piece of iron but is incorporated in the 'altar'.

17 Naden [ed.] 1985, Kröger 1982: 8.

18 Also glossed "sacrifice" (113) and "initiation rites of a secret society" (52).

19 J. Goody identifies bore and bagre (SOL: 52); the dialect of his LoWiili shares the feature that "the voicedness of $/ \mathrm{b} /$ and even of $/ \mathrm{g} /$ undergoes regressive assimilation to a preceding / $a /{ }^{115}$ as in BR and in the DG of Pénou-Achille from whom the quote comes: it gives its grave character to yield a back / round vowel - Pénou-Achille's examples \{dab+lu\} -> /doolu/ "manliness", $($ pog $+\emptyset]$-> /pow/ "woman".

20 The -1- in BL may be a thematic extensor consonant (Manessy 1975: 133f.) or a second morpheme: the latter could explain the change of class from II to IV, but note that in "fire" "BUG - ${ }^{*} \mathrm{LAM}$ with the second member of the compound attested in the E.O/V languages (Bicri (P) daam, (Dp) lam) yields BL bolem with loss of the $-\mathrm{g}$ -

21 "-IG- ->-iu- see note 19.

22 Or is it ba'ayubugri? - ba'ayuya being used for "divinatory" (Vocabulary \#2 above), i.e. "(sacrifice to his) divinatory shrine".

23 Also more general reference.

24 Could this be "WO-, "WE-, or "YO-KU/-TI - bush' (hunting) shrine?

25 Under PWN "TI Mukarovsky (1977) lists both "ti-ka "tree" forms and "ti-m "medicine" words: Common Bantu *ti also yields both senses (presumably with different class prefixes).

26 I therefore suspect the separateness of the two Grusi reconstructions "root" "LI/U and "medicine" LI/U(D) in Manessy 1969.

27 In many groups the funeral rites incorporate some ceremony to divine whether the death was caused by witchcraft.

\section{References}

\section{A Sources of vocabulary in Part 2}

(J) Lists in JWAL article, Swadesh et al. 1966

(R) Lists in Rattray, 1932

(N) personal research (Naden)

DB Dagbani: printed sources, (FS) Fisch 1913, (N), (OP) Oppong, (O) Okraku

NN Nanun: personal research, (Sk) Skalnik 1983

MP Mampruli: personal research, Drucker Brown RAMK

HG Hanga: printed sources, $(\mathrm{H})$ p.c. Geoffrey Hunt

KR KaMara: Bouna dialect Prost 1974b (P); Ghana dialect (N), (H) p.c. Geoffrey Hunt

KLA Kusaal, Agole (Eastern) dialect: printed sources, (N)

KLT Kusaal, Toondi (Western) dialect: notes by David and Nancy Spratt (S), (N)

NB Nabit: (N), (R), (J) 
TL Talni: Fortes 1945, 1949 (F), (N), written list by Abraham Manga for Naden (A), (GG) two lady informants recorded by Naden

FR Frafra: written sources, p.c. Bob / Nancy Schaefer

GN Gurenne: $(\mathrm{J})$ - origin unrecorded

NK Nankan: (N), (R) (may not be same dialect)

MR Moore: printed sources, Hall n/d (1948) (H), Canu, Tiendrebeogo / Pagéard

NT Nootre: Prost 1971, 1974a, 1975

DG Dagara: Burkina Faso (J), Pénou-Achille

DR Dagaari: (J), Ed Hall notes / files (H), (G) J. Goody - (SOL, MBG)

LW LoWiili: (G) J. Goody - (SOL, MBG)

NR Nura (Dagaari of Lawra): (J), Kennedy 1966 (K)

LB Lobiri(? = NR): (R)

BR Birifor: (J), (K) Larry Kuch (p.c.)

WL Waali: GILLBT files

SF Safalaba: (O), (N)

BL Buli: (FK) Franz Kröger - (AW) 1982, (D) 1992, GILLBT files (Ian Gray, Todd Poulter, Paul Dancy), (N), Melançon / Prost 1972 (P)

KM Konni: (N), Naden 1986, Cahill

BM Bimoba: published sources, Norman Price p.c., GILLBT files (Jill Jacobs, Sonia Hine)

PWN Proto Western Nigritic: reconstructions of Mukarovsky 1977, 1976

W.O/V Western Oti / Volta: reconstructions and summary forms of Manessy 1975, Naden 1989, Lexinotes, personal research.

\section{B Works Cited}

Abasi, Augustine Kututera. 1995. LUA-LIA, the "Fresh Funeral": Founding a House for the Deceased among the Kasena of North-east Ghana. Africa 65(3): 448-475.

Arozenara, Pierre. 1975. Notes à propos de quelques instruments de musique mossi. Ouagadougou. Notes et Documents Voltaiques 3: 39-53.

Barker, Peter. 1986. Peoples, Languages and Religion in Northern Ghana - A Preliminary Report. Accra: Asempa / G.E.C.

BIBLE (MR). 1983. Wênnaam Sebre ne Moore: La Bible en Mooré. Lomé: Société Biblique en Afrique Occidentale.

Bourdillon, M.F.C. and M. Fortes (Eds.). 1980. Sacrifice. London, N.Y.C.: Academic Press.

Brown, Cecil H. 1984. Language and Living Things: Uniformities in Folk Classification and Naming. New Brunswick, N]: Rutgers University Press.

Brown, Cecil H. 1986. The Structure of Folk Biological Categories and the Perceptual Basis of Life-form Classes. Manuscript.

Cahill, Mike. 1993. What! No Prepositions? Cahill, M. (Ed.). 1993: 7-9.

Cahill, Mike. 1993. Vowel Harmony and Underspecification in Konni. Cahill, M. (Ed.). 1993: 10-17.

Cahill, Mike (Ed.I. 1993. Papers from G.I.L.L.B.T.'s Seminar Week: 1-5 February 1993. Tamale, N.R.: G.I.L.L.B.T. 
4, Gaston. 1968/71. Gúrénnè et Mo:rẽ. WALS / SLAO 1968/71: 265-283. rugu. African Music 7(2): 58-71

Deschamps, Hubert. 1972. Les religions de l'Afrique noire. Paris: PUE.

Drucker Brown, Susan. 1975. Ritual Aspects of Mamprusi Kingship (RAMK). Leiden: Afrika-Studiecentrum / Cambridge: African Studies Centre.

Flsch, Rudolf. 1913. Wörtersammlung Dagbané-Deutsch. MSOS 16: 113-214.

Fortes, Meyer. 1945. The Dynamics of Clanship among the Tallensi. London: OUP.

Fortes, Meyer. 1949. The Web of Kinship among the Tallensi. London: OUP.

Fortes, Meyer. 1980. Preface: Anthropologists and Theologians: Common Interests and Divergent Approaches. Bourdillon, M.F.C. and M. Fortes (Eds.). 1980; v-xix.

Goody, Esther N. 1978. Towards a Theory of Questions. E. Goody (Ed.). 1978: 17-43.

Goody, Esther N. (Ed.). 1979. Questions and Politeness: Strategies in Social Interaction. Cambridge, Cambs.: CUP.

Goody, Jack. 1956. Second edition. 1961. Social Organisation of the LoWiili (SOL). London: OUP for IAI.

Goody, Jack. 1972. The Myth of the Bagre (MBG). London, Oxford: OUP.

Hall, John F. s.a. (1948). Dictionary and Practical Notes, Mossi-English Languages. Ouagadougou: Mission des Assemblées de Dieu.

Hunt, Geoffrey R. and Rosemary Hunt. 1981. A Phonology of the Hanga Language. Legon: IAS.

Jacobs, Gillian G. 1970. Bimoba Syntax. Legon: IAS.

Kennedy, Jack. 1966. Phonology of Dagaari. Legon: IAS.

Kopytoff, Igor. 1971. Ancestors as Elders in Africa. Africa 41(2): 129-142.

Kröger, Franz. 1982. Ancestor Worship among the Bulsa of Northem Ghana. Höhenschäftlam: Klaus Renner.

Kröger, Franz. 1992. Buli-English Dictionary. Münster, Hamburg: Lit.

Kuper, Adam. 1982. Lineage Theory: A Critical Retraspect. Annual Reviews of Anthropology 1: 7195.

Manessy, Gabriel. 1969. Les langues gurunsi (2 vols.). Paris: SELAF.

Manessy, Gabriel. 1975. Les langues Oti / Volta. Paris: SELAF.

MBG see Goody, J. 1972.

Mbiti, John S. 1969. African Religions and Philosophy. London: SPCK.

Mbiti, John S. 1970. Concepts of God in Africa. London: SPCK.

McCall, John C. 1995. Rethinking Ancestors in Africa. Africa 65(2): 256-270. .

Melançon, Lucien and Andrê Prost (R.PP.), 1972. Dictionnaire buli-français. Dakar: Univ. de Dakar.

Mendonsa, Eugene L. 1973. Divination Among the Sisala of Northern Ghana. Unpublished PhD dissertation, Univ. of Cambridge.

Mendonsa, Eugene L. 1976. Elders, Office Holders and Ancestors among the Sisala of Northern Ghana. Africa 46: 57-65.

Mendonsa, Eugene L. 1982. Politics and Divination. Berkeley: Univ. California.

Mukarovsky, Hans. 1976. A Study of Western Nigritic II. Wien: Institut für Ägyptologie und Afrikanistik der Universität Wien. 
Mukarovsky, Hans. 1977. A Study of Western Nigritic I. Wien: Institut für Aegyptologie und Afrikanistik der Universität Wien.

N\&\& see R.A.I. 1951.

Naden, Anthony J. 1982. Class Pronoun Desuetude Revisited. JWAL XII(1): 34-42.

Naden, Tony (Ed.). 1976. Kinship Terminology: and Some of the Social Correlates or Outworkings of the Kinship System in Ghanaian Culture. Legon: IAS.

Naden, Tony (Ed.). 1984. Law in Some North-Ghanaian Societies. Legon: IAS.

Naden, Tony. 1986. Social Context and Mampruli Greetings. Huttar, George and Kenneth Gregerson (Eds.). Pragmatics in a Non-Western Perspective. Dallas: S.I.L. / University of Texas at Arlington [SILPL \#73] : 161-199.

Naden, Tony. 1988. Gur Languages. Dakubu, Mary Esther Kropp (Ed.). The Languages of Ghana. London: Kegan Paul International for IAI / WALS: 12-49.

Naden, Tony. 1989. Gur. Bendor-Samuel, J.T. (Ed.). 1989. The Niger-Congo Languages. Lanham, MD.: University Press of America: 141-168.

Naden, Tony. 1993. From Wordlist to Comparative Lexicography: The Lexinotes. Lexikos 3: 167-190.

Naden, Tony. Forthcoming. Time and Calendar in Mampruli. Naden (Ed.). Forthcoming: 25-42.

Naden, Tony (Ed.). Forthcoming Time and the Calendar in Ghana. Legon: IAS.

Naden, Tony. Manuscript. Notes on the KaMara of Larabanga.

New Testament (KL). 1976. Wina'am Gbon Nonapaal: (New Testament) Kusaal. Wycliffe Bible Translators / World Home Bible League.

New Testament (HG). 1983. Naawun Bukupaali: The New Testament in Hanga. International Bible Society / World Home Bible League.

New Testament (FR). 1986. Na'ayene Goypaalom: Farefare. International Bible Society.

New Testament (DB). 1982. Naawuni Kundi Palli: New Testament in Dagbani. Accra: Bible Society of Ghana.

Newell, W.H. (Ed.). 1976. Ancestors. The Hague: Mouton.

Nkrumah, Sylvester. 1993. Concepts of the Supernatural Among the Akyode. Cahill (Ed.). 1993: 45-64.

OED. 1933. A New English Dictionary on Historical Principles. London, Oxford: Clarendon, OUP.

Okraku, John S. 1917. Dagomba Grammar (with exercises and vocabularies). Oxford: OÚP.

Oppong, Christine. 1973. Growing Up in Dagbon. Tema: Ghana Publishing Corpn.

Otto, Rudolf. 1923 / 1950. The Idea of the Holy. London: OUP.

Pénou-Achille, S. 1982. Systématiqué du signifiant en dagara. Paris: L'Harmattan.

Prost, André (R.P.). 1971. Nōtre et moore. Notes et Documents Voltaïques 5(1): 25-30.

Prost, André (R.P.). 1974a. Notes sur le kamara de Bouna. Abidjan: Annales de l'Université d'Abidjan série $H$ VIl: 75-93.

Prost, André (R.P.). 1974b. Les langues de l'Atakora: VII. Le nõtre, langue des Nōtaba dits Bulba. BIFAN 36, B(3): 628-659.

R.A.I. 1951 ${ }^{16}$. Notes and Queries on Anthropology. London: RKP for Royal Anthropological Institute.

RAMK see Drucker Brown. 1975.

Rapp, Eugen L. 1966. Die Gurenne-Sprache in Nordghana., Leipzig: VEB Verlag Encyklopädie.

Rattray, R.S. 1932. Tribes of the Ashanti Hinterland. (2 Vols.). Oxford, London: OUP. 
Riggs, Fred W. 1986. The Interdisciplinary Tower of Babel. Prepub. draft.

Rosch, Elinor, Carolyn B. Mervis, Wayne Gray, David Johnson and Penny Boyes-Braem. 1975.

Basic Objects in Natural Categories. Berkeley: University of California at Berkeley.

Sarpong, Peter. 1974. Ghana in Retrospect. Accra: Ghana Publishing Corporation.

Schaefer, Nancy and Patrick Adongo. Forthcoming. Notes on the Frafra Time System. Naden

(Ed.). Forthc.: 19-24.

Schaefer, Robert L. 1975. The Phonology of Frafra. Legon: IAS.

Skalnik, Peter. 1983. Questioning the Concept of the State in Indigenous Africa. Social Dynamics 9(2): 11-28.

SOL see J. Goody. 1956 / 1961.

Some, Bemard B. 1970. La religion traditionelle mossi comme source de valeurs de civilisation politique. Notes et Documents Voltaiques 4(1): 3-31.

Spratt, David and Nancy Spratt. s.a. a. Kiusaal-English Dictionary. Tamale: Ghana Institute of Linguistics (now GILLBT).

Spratt, David Nancy Spratt. s.a. b. An Introduction to Learning Kusaal. Tamale: Ghana Institute of Linguistics. (now GILLBT).

Spratt, David and Nancy Spratt. 1968. The Phonology of Kusaal. Legon: I.A.S.

Spratt, David and Nancy Spratt. 1972. Kusaal Syntax. Legon: I.A.S.

Swadesh, Mauricio, Evangelina Arana, John T. Bendor-Samuel and W.A.A. Wilson. 1966. A Preliminary Glottochronology of Gur Languages. J.W.A.L. III (1): 27-65.

Teviu, Adjewo and John C. Callow. s.a. (1969?). The Founding of Paga. Legon: I.A.S.

Tiendrebeogo, Yamba and Robert Pagéard. 1975. Dictons mossi sur les devins. Notes et Documents Voltä̈ques 8(3): 37-8.

Tolkien, John R.R. 1964. Tree and Leaf. London: Allen and Unwin.

Tuurey, G. 1982. An Introduction to the Mole-speaking Community. Wa, UWR: Wa Catholic Press.

WALS / SLAO. 1969 / 1971. Actes du huitième congrès international de linguistique africainen. Abidjan: Annales de l'Univ. d'Abidjan, 1971, Série H: fasc. hors série.

Wumbillah, Joseph B. s.a. (1970s). The Kusaas People of Northern Ghana. Unpublished MS.

Zwememann, J. 1961. Les notions du dieu-ciel chez quelques tribus voltaïques. Etudes Volts. 2: 71-100. 